Web Jurnal:

http://ejournal.kemenperin.go.id/jli

\title{
Pengaruh ukuran saringan dan konsentrasi gula terhadap sifat fisika kimia konsentrat sari buah kundur (Benincasa hispida (Thunb.) Cogn)
}

\section{The Effect of filter size and sugar concentration on the physicochemical properties of kundur (Benincasa hispida (Thunb.) Cogn) fruit juice concentrate}

Inda Three Anova*, Kamsina Kamsina, Firdausni Firdausni, Yulia Helmi Diza, dan Yurnita Yurnita

Balai Riset dan Standardisasi Industri Padang

Jl. Raya LIK No. 23 Ulu Gadut, Padang Indonesia

* e-mail: indova@gmail.com

\begin{tabular}{|c|c|}
\hline INFO ARTIKEL & ABSTRAK \\
\hline Sejarah artikel: & Buah kundur (Benincasa hispida (Thunb.) Cogn) telah banyak dimanfaatkan oleh \\
\hline Diterima: & masyarakat sebagai salah satu bahan pangan fungsional. Pemanfaatan buah kundur \\
\hline 19 Oktober 2021 & biasanya dengan cara dibuat sari buah yang diminum langsung atau dikombinasikan \\
\hline Direvisi: & dengan campuran sari buah lainnya. Kandungan buah kundur terdiri dari air, protein, \\
\hline 17 Desember 2021 & karbohidrat, serat vitamin dan mineral. Tujuan dari penelitian ini adalah untuk melihat \\
\hline Diterbitkan: & pengaruh dari perlakuan variasi ukuran saringan yaitu 40 mesh, 60 mesh, 80 mesh, dan \\
\hline & $\begin{array}{l}\text { konsentrasi gula yaitu } 30 \% \text { dan } 40 \% \text { yang digunakan pada pembuatan konsentrat sari } \\
\text { buah kundur. Terhadap konsentrat vang diperoleh dilakukan pengamatan } \mathrm{pH} \text {, kekentalan. }\end{array}$ \\
\hline Kata kunci: & analisa kadar serat, kadar gula, mineral, vitamin $\mathrm{C}$ dan aktivitas antioksidan. Perlakuan \\
\hline Benincasa hispida & ukuran saringan 40 mesh dengan konsentrasi gula $40 \%$ memberikan hasil yang optimal \\
\hline (Thunb.) Cogn; & dengan $\mathrm{pH} 4,87$, kekentalan $12,09 \mathrm{cP}$, kadar serat $0,15 \%$, kadar gula $29,91 \%$, kandungan \\
\hline buah kundur; & mineral kalsium $(\mathrm{Ca})$ 0,0002\%, magnesium $(\mathrm{Mg})$ 0,0057\%, kalium $(\mathrm{K})$ 0,0474 \% dengan \\
\hline $\begin{array}{l}\text { konsentrat; } \\
\text { saringan }\end{array}$ & nin C $0,0057 \%$ dan aktivitas antioksidan 55,65\%. \\
\hline
\end{tabular}

\section{Keywords:}

Benincasa hispida

(Thunb.) Cogn;

kundur fruit;

concentrate;

sieve

\begin{abstract}
Kundur fruit (Benincasa hispida (Thunb.) Cogn) has been widely used by the community as a functional food ingredient. Kundur fruit is usually made into fruit juice which is drunk directly or combined with other fruit juice mixtures. The content of kundur fruit consists of water, protein, carbohydrates, fiber, vitamins, and minerals. The purpose of this study was to see the effect of 40 mesh, 60 mesh, 80 mesh sieve size variation treatment and sugar concentrations of $30 \%$ and $40 \%$ were used in the processing of kundur fruit juice concentrate. The concentrates were observed for $\mathrm{pH}$, viscosity, analysis of fiber content, sugar content, minerals, vitamin $C$, and antioxidant activity. Treatment of 40 mesh sieve size, 40\% sugar concentration gave the optimal results with pH 4.87, viscosity $12.09 \mathrm{cP}$, fiber content $0.15 \%$, sugar content $29.91 \%$, mineral content calcium (Ca) $0.0002 \%$, magnesium $(\mathrm{Mg}) 0.0057 \%$, potassium $(\mathrm{K}) 0.0474 \%$ with vitamin $C$ content of $0.0057 \%$ and $55.65 \%$ antioxidant activity.
\end{abstract}

\section{Pendahuluan}

Bahan pangan merupakan sumber gizi yang berperan dalam menjaga kesehatan manusia yang mengkonsumsinya. Bahan pangan tersebut pada umumnya tidak hanya dikonsumsi dalam bentuk segar, tetapi sebagian besar diolah menjadi berbagai bentuk dan jenis pangan yang lain. Hal itu dilakukan untuk memperpanjang umur simpan dalam bentuk lain yang bergizi dan mengurangi persentase kerusakan pada bahan pangan (Bastanta et al., 2017). 
Tanaman kundur (Benincasa hispida (Thunb.) Cogn) merupakan tanaman yang termasuk di dalam famili Cucurbitae atau sejenis labu (Chen and Huang, 2019; Ekeke et al., 2019; Luhurnintyas et al., 2018). Buah ini kaya karbonat, pektin, garam mineral, vitamin dan labu polisakarida, yang bermanfaat bagi kesehatan. Selain sebagai sayuran (Suryanti et al., 2018; Zaini et al., 2011). Secara tradisional dan turun menurun digunakan sebagai laksatif, diuretik, dispepsia, dan anti inflamasi dan juga bersifat hipoglikemik, hipolipidemik dan efek antikanker (Chen and Huang, 2019; Kumar et al., 2020). Selain itu, juga dapat menghilangkan berbagai radikal bebas yang dihasilkan dalam tubuh selama metabolisme, termasuk anion superoksida, radikal hidroksil, dan spesies oksigen reaktif lainnya (Chen and Huang, 2019).

Penelitian-penelitian pemanfaatan serta pengolahan tanaman kundur (Benincasa hispida (Thunb.) Cogn) telah cukup banyak dilakukan, diantaranya : potensi kundur sebagai sumber nutrisi dan pangan fungsional (Zaini et al., 2011), kuantifikasi vitamin C pada $B$. hispida yang diekstrak menggunakan pelarut yang berbeda (Fatariah et al., 2015), penambahan sari jeruk nipis pada mutu sirup buah kundur (Hamidi et al., 2016), tanaman obat untuk perlindungan pencernaan (Al-Snafi, 2018), pengaruh metode pengolahan terhadap stabilitas, rasa dan kandungan nutrisi jus buah kundur (Sun et al., 2018), karakteristik secara morfologi dan anatomi (Ekeke et al., 2019).

Sebagai anti jamur dan identifikasi metabolit sekunder menunjukkan ekstrak etanol biji kundur positif mengandung alkaloid, flavonoid, dan saponin (Luhurnintyas et al., 2018), sebagai anti bakteri (Mubarak et al., 2018), sebagai tanaman obat/farmasi, anti radikal bebas (Al-Snafi, 2018, 2013), isolasi dan identifikasi senyawa kimia buah kundur (Benincasa hispida) dengan kromatografi kolom (Suryanti et al., 2018), pengaruh kultivar dan pengolahan jus B. hispida terhadap nutrisi, rasa dan stabilitas jus (Sun et al., 2018), pengaruh kundur pada fisikokimia mutu roti selama penyimpanan (Das et al., 2019), isolasi dan identifikasi senyawa prekussor pada jus kundur (Pan et al., 2020) .

Buah kundur di Sumatera Barat banyak dibudidayakan sebagai tanaman pekarangan, dan pengolahannya masih terbatas, sehingga belum adanya olahan sari buah kundur dalam bentuk konsentrat. Konsentrat adalah juice yang telah mengalami pengurangan kadar air dalam jumlah tertentu melalui proses pengeringan baik secara alami ataupun dipaksakan. Dalam semua kasus, pengeringan terjadi melalui penguapan proses yang memisahkan air dari jus buah dengan menggunakan energi panas. Penguapan dapat dilakukan dalam batch atau secara terus menerus untuk menghasilkan cairan pekat yang dapat dipompa. Ada beberapa jenis evaporator tetapi yang didasarkan pada konfigurasi termal cerdas sebagian besar disukai karena efisiensi energinya yang lebih tinggi (Adnan et al., 2018).

Secara umum pada teknologi konsentrat, setelah sari buah dipekatkan hanya sedikit kemiripannya dengan produk alami meskipun diencerkan kembali ke konsentrasi aslinya. Hal ini disebabkan karena sebagian besar nutrisi jus buah dan zat sensorik sangat sensitif pada saat pengolahan. Walaupun rasa jus buah tertentu dapat ditingkatkan dengan zat tambahan, tetapi hal ini tidak berlaku untuk semua jenis sari buah. Dalam pembuatan konsentrat buah-buahan perlu dipertimbangkan metode yang tepat, sehingga kehilangan nilai nutrisi, sensorik dan kandungan antioksidan dari buah tersebut dapat diminimalisir (Adnan et al., 2018; Bhattacharjee et al., 2017). Tujuan dari penelitian ini adalah untuk melihat pengaruh dari perlakuan variasi ukuran saringan dan konsentrasi gula yang digunakan pada pembuatan konsentrat buah kundur.

\section{Metode}

\subsection{Bahan dan peralatan}

Bahan baku utama dari penelitian ini adalah kundur (B. hispida). Kundur diperoleh dari petani lokal daerah Kuranji Padang. Bahan penolong yaitu gula pasir, carboxymethyl cellulose (CMC). Peralatan yang digunakan diantaranya adalah: juicer, saringan ukuran 20, 40 dan 80 mesh, wadah plastik, spatula, dan peralatan gelas.

Proses pemekatan konsentrat sari buah kundur dilakukan dengan menggunakan alat destilasi vakum evaporator (Heidolph Laborata 4000 efficient) pada suhu $60^{\circ} \mathrm{C}$ dengan waktu 90 menit.

\subsection{Rancangan penelitian}

Penelitian pembuatan konsentrat dilakukan dengan perlakuan variasi ukuran saringan 20 mesh (M1), 40 mesh (M2) dan 80 mesh (M3) dan pemakaian konsentrasi gula 20\% (C1) dan 40\% (C2). Rancangan percobaan yang dilakukan Rancangan Acak Lengkap (RAL) secara faktorial dan data yang didapatkan dilakukan pengolahan secara statistik.

\subsection{Proses pembuatan konsentrat}

Pembuatan konsentrat sari buah kundur dilakukan atas dua tahapan, yaitu proses pembuatan sari buah kundur dan proses evaporasi sari buah menjadi konsentrat. Pada proses pembuatan sari buah dilakukan proses ekstraksi, buah dipilih yang bagus/tidak cacat, dicuci, dipotong-potong kemudian di press dengan menggunakan juice extractor, sehingga terpisah antara sari buah dan ampasnya. Sari buah yang didapatkan kemudian dilakukan karakterisasi dan variasi proses penyaringan sesuai dengan perlakuan, yaitu : saringan 20 mesh (M1), 40 mesh (M2) dan 80 mesh (M3). Sari buah yang telah disaring kemudian dilakukan penambahan konsentrasi gula cair sesuai dengan perlakuan, yaitu : 20\% (C1) dan 40\% (C2) kemudian dilakukan pengadukan hingga semua gula larut sempurna. Pada tiap perlakuan sari buah kundur kemudian dilakukan pengurangan kadar air menggunakan vakum evaporator pada suhu $60^{\circ} \mathrm{C}$ selama 90 menit dengan volume awal masing-masing perlakuan sebanyak $1000 \mathrm{ml}$. Kemudian konsentrat di masukkan dalam kemasan botol yang terlebih dahulu telah dilakukan proses sterilisasi. Pada konsentrat buah kundur yang didapatkan, selanjutnya dilakukan pengamatan. 


\subsection{Pengamatan}

Pada sari buah dilakukan pengamatan antara lain : $\mathrm{pH}$, TDS (Brix), serat kasar (\%), antioksidan (\%), vitamin $\mathrm{C}(\%)$, dan beberapa kandungan mineral Besi $(\mathrm{Fe})$, Kalsium (Ca), Magnesium (Mg) dan Kalium (K). Pada konsentrat juga dilakukan pengamatan seperti halnya pada sari buah kundur, yaitu : $\mathrm{pH}$, kekentalan (cP), kadar TSS (Brix), serat kasar (\%), antioksidan (\%), vitamin $\mathrm{C}(\%)$, dan total fenol (mgGAE/gr).

\section{Hasil dan pembahasan}

\subsection{Analisa terhadap sari buah kundur}

Terhadap sari buah kundur dilakukan pengamatan seperti tampak pada Tabel 1. Hasil menunjukkan bahwa nilai kadar gula sari buah kundur cukup rendah yaitu 2 Brix. Rendahnya nilai kadar gula menyebabkan rasa dari sari buah kundur ini kurang manis atau hambar sehingga perlu ditambahkan pemanis/gula atau buah lain yang lebih manis, sehingga dapat meningkatkan rasa manis dari sari buah kundur.

Selain kadar gula glukosa, terhadap sari buah kundur juga dianalisa serat kasar, aktivitas antioksidan, vitamin $\mathrm{C}$ dan beberapa logam mineral yang terdapat pada sari buah kundur. Hasil pengamatan terhadap sari buah ternyata mengandung kadar serat kasar sekitar 0,28\%. Kadar serat walaupun bukan merupakan unsur gizi yang penting tapi cukup memegang peranan dalam proses pencernaan dalam tubuh manusia. Jika dibandingkan dengan nilai kadar serat kasar dari buah, maka kadar serat kasar dari sari buah ini jauh lebih rendah, hal ini bisa disebabkan dalam pengolahan pembuatan sari buah telah dilakukan tahap penyaringan, sehingga kadar serat dari sari buah yang dihasilkan menjadi rendah.

Tabel 1.

Hasil analisa sari buah kundur

\begin{tabular}{lll}
\hline Parameter & Satuan & Nilai \\
\hline Kadar gula & Brix & 2 \\
Serat kasar & $\%$ & 0,28 \\
Aktivitas Antiokasidan & $\%$ & 29,81 \\
Vitamin C & $\%$ & 0,0059 \\
Fe (Besi) & $\%$ & 0,0005 \\
Ca (Kalsium) & $\%$ & 0,0055 \\
Mg (magnesium) & $\%$ & 0,0064 \\
K (Kalium) & $\%$ & 0,0799 \\
pH & - & 5,14 \\
\hline
\end{tabular}

Kandungan mineral pada sari buah juga cukup bervariasi, terdapat zat besi, kalsium, magnesium dan kalium yang tinggi. Tingginya kadar kalium ini sangat cocok untuk penderita hipertensi. Pada sari buah kundur juga mengadung aktivitas antioksidan seperti tampak pada Tabel 1, yaitu sekitar 29,81\%. Aktivitas antioksidan ini berhubungan erat dengan kandungan vitamin $\mathrm{C}$. Kadar vitamin $\mathrm{C}$ yang terdapat pada sari buah kundur di penelitian ini sekitar 0,0059\%. Hal ini menunjukkan bahwa sari buah kundur ini cukup mengandung nilai gizi yang tinggi dimana terdapat juga kadar vitamin $\mathrm{C}$ yang dibutuhkan oleh tubuh.

\subsection{Pengamatan terhadap konsentrat sari buah kundur}

Terhadap konsentrat sari buah yang didapatkan dilakukan pengamatan terhadap $\mathrm{pH}$, kekentalan serta pengujian terhadap kadar serat kasar, kadar gula dan kandungan beberapa mineral (Tabel 2). pH Konsentrat yang dihasilkan berkisar dari yang paling tinggi yaitu 5,18 dan yang terendah pada nilai 4,79. Nilai $\mathrm{pH}$ konsentrat secara umum cenderung dibawah $\mathrm{pH}$ normal atau sedikit asam dan tidak terdapat pengaruh perlakuan pada nilai $\mathrm{pH}$ yang dihasilkan. Produk yang mempunyai $\mathrm{pH}$ yang lebih rendah memiliki ketahanan yang lebih tingggi dibandingkan produk yang mempunyai $\mathrm{pH}$ yang lebih rendah. Bila dibandingkan dengan $\mathrm{pH}$ dari sari buah kundur, rata-rata $\mathrm{pH}$ setelah jadi konsentrat sedikit mengalami penurunan atau lebih asam.

Tabel 2.

Analisa konsentrat sari buah kundur

\begin{tabular}{lclll}
\hline & \multicolumn{4}{c}{ Analisa } \\
\cline { 2 - 5 } Perlakuan & $\mathbf{p H}$ & $\begin{array}{l}\text { Kekentalan } \\
(\mathbf{c P})\end{array}$ & $\begin{array}{l}\text { Serat } \\
\text { kasar } \\
(\%)\end{array}$ & $\begin{array}{l}\text { Kadar } \\
\text { Gula } \\
(\%)\end{array}$ \\
\hline M1C1 & 5,18 & 10,8 & 0,19 & 22,81 \\
M1C2 & 4,85 & 12,9 & 0,15 & 29,91 \\
M2C1 & 4,93 & 8,8 & 0,11 & 24,76 \\
M2C2 & 4,79 & 11,5 & 0,09 & 35,65 \\
M3C1 & 4,96 & 8,0 & 0,06 & 24,22 \\
M3C2 & 4,82 & 10,7 & 0,04 & 36,25 \\
\hline
\end{tabular}

(saringan 20 mesh, konsentrasi gula 40\%), M2C1 (saringan 40 mesh, konsentrasi gula 20\%), M2C2 (saringan 40 mesh, konsentrasi gula 40\%), M3C1 (saringan 80 mesh, konsentrasi gula 20\%), M3C2 (saringan 80 mesh, konsentrasi gula 40\%).

Pengamatan kekentalan konsentrat yang dihasilkan (Tabel 2) terlihat bahwa kekentalan sari buah paling rendah terdapat pada perlakuan penyaringan 80 mesh konsentrasi gula 40\% (M3C2) dengan nilai 8,0cP dan kekentalanan tertinggi pada perlakuan penyaringan 20 mesh konsentrasi gula 40\% (M1C2) dengan nilai $12,9 \mathrm{cP}$. Perbedaan ukuran penyaringan dan perbedaan pemakaian konsentrasi gula akan berpengaruh pada nilai kekentalan, semakin tinggi ukuran mesh pada penyaringan sari buah akan menghasilkan nilai kekentalan yang semakin rendah, dan semakin tinggi konsentrasi gula yang digunakan akan menyebabkan semakin kental konsentrat yang dihasilkan. Terjadinya perbedaan kekentalan juga bisa disebabkan sewaktu dilakukan proses penyaringan dengan ukuran mesh yang berbeda, dimana semakin besar ukuran mesh saringan/ukuran pori semakin kecil, akan menghasilkan sari buah yang semakin jernih, dan berlaku sebaliknya.

Dari Tabel (2) juga terlihat bahwa nilai kekentalan selain dipengaruhi oleh ukuran saringan sari buah yang digunakan, juga dipengaruhi oleh konsentrasi gula. Pemakaian konsentrasi gula yang lebih rendah yaitu $20 \%$ (C1) memiliki nilai kekentalan lebih rendah dibandingkan dengan konsentrat yang memiliki kadar gula yang lebih tinggi (C2), jika dilihat hubungan antar ukuran saringan dan konsentrasi gula tampak bahwa semakin kecil mesh saringan pada konsentrasi gula yang lebih tinggi akan menghasilkan konsentrat yang semakin kental. Peningkatan viskositas salah satunya dipengaruhi 
oleh konsentrasi gula yang ditambahkan (Asmawati et al., 2018; Fitri et al., 2017).

Serat kasar dari konsentrat sari buah berkisar diantara 0,4-0,19\% setelah dilakukan pengamatan. Besar kecilnya kadar serat dipengaruhi oleh perlakuan saringan mesh yang berbeda. Hal ini dikarenakan semakin besar ukuran pori saringan akan menyebabkan akan semakin banyak serat bersama sari buah yang lolos saringan sehingga akan meningkatkan kadar serat kasar dari konsentrat yang didapatkan. Nilai serat kasar tertinggi didapatkan pada perlakuan $\mathrm{M} 1 \mathrm{C} 1$ dan paling rendah didapatkan pada perlakuan M3C2. Nilai kadar serat kasar dari konsentrat jika dibandingkan dengan kadar serat kasar awal dari sari buah kundur terjadi penurunan.

Serat kasar adalah suatu residu tidak larut yang dihasilkan dari reaksi hidrolisis asam dan hidrolisis basa yang berupa selulosa murni dan lignin tidak larut. Kualitas serat pangan ditentukan oleh komponen serat makanan yang dikandungnya mencakup komponen yang larut dan komponen yang tidak larut. Komponen dari serat kasar ini kurang mempunyai nilai gizi, akan tetapi serat ini sangat penting untuk proses memudahkan dalam pencernaan di dalam tubuh agar proses pencernaan tersebut lancar (Yulia et al., 2020).

Kadar gula dari konsentrat sari buah paling rendah didapatkan pada perlakuan M1C1 yaitu $22,81 \%$ dan yang tertinggi didapatkan pada perlakuan $\mathrm{M} 3 \mathrm{C} 2$ dengan nilai $36,25 \%$. Hal ini sesuai dengan perlakuan yang diberikan, dimana semakin tinggi konsentrasi gula yang ditambahkan semakin tinggi kadar gula reduksi dari konsentrat buah yang didapatkan serta jika dilihat dari nilai kekentalan konsentrat terjadi peningkatan kadar gula seiiring dengan tingkat kekentalan konsentrat yang dihasilkan. Jika dibandingkan dengan SNI sirup, maka konsentrat yang didapatkan belum memenuhi, ini dikarenakan jumlah konsentrasi gula yang ditambahkan memang masih jauh dibawah standar yang seharusnya.

Semakin banyak konsentrasi gula yang ditambahkan maka akan meningkatkan kadar sukrosa yang ada. Gula pasir terdiri dari sebagian besar sukrosa yaitu $95 \%$ dan beberapa komponen non sukrosa, sehingga dengan penambahan gula dari luar maka dengan sendirinya akan bertambah bagian sukrosanya, sehingga kadar sukrosa pada konsentrat buah kundur meningkat (Fitri et al., 2017).

Terhadap konsentrat sari buah juga telah dilakukan pengamatan kandungan mineral, didapatkan bahwa konsentrat sari buah memiliki kandungan mineral magnesium dan kalium yang cukup tinggi. Hal ini juga terlihat pada pengamatan kandungan mineral sari buah muni kundur, dimana angka untuk kandungan mineral magnesium $(\mathrm{Mg})$ adalah 0,011\% dan kalium (K) 0,076\%. Jika dibandingkan antar keduanya, maka terlihat bahwa kandungan kedua jenis mineral tersebut setelah di jadikan konsentrat menjadi lebih tinggi. Hal ini kemungkinan disebabkan karena konsentrat lebih pekat setelah dikurangi kadar airnya, dan telah ditambahkan konsentrasi perlakuan gula.

Dari Gambar 1 terlihat bahwa kandungan mineral Magnesium $(\mathrm{Mg})$ konsentrat kundur berkisar diantara 0,003-0,009\%, dengan nilai tertinggi terdapat pada perlakuan $\mathrm{M} 3 \mathrm{C} 2$, kandungan besi $(\mathrm{Fe})$ pada nilai $0,02-$ 0,04\%, sedangkan untuk kandungan mineral Kalium (K) konsentrat berada diantara 0,024-0,076\%, dengan nilai tertinggi juga terdapat pada perlakuan M3C2. Terjadinya hal ini kemungkinan disebabkan juga karena telah mendapatkan perlakuan penambahan konsentrasi gula, sehingga kadar total mineral konsentrat telah merupakan campuran dari semua mineral bahan yang telah dicampurkan. Jika dibandingkan dengan kadar mineral kalium awal pada kadar sari buah, terlihat bahwa kadar mineral kalium pada sari buah memang merupakan kadar mineral yang paling tinggi dibandingkan mineral lainnya.

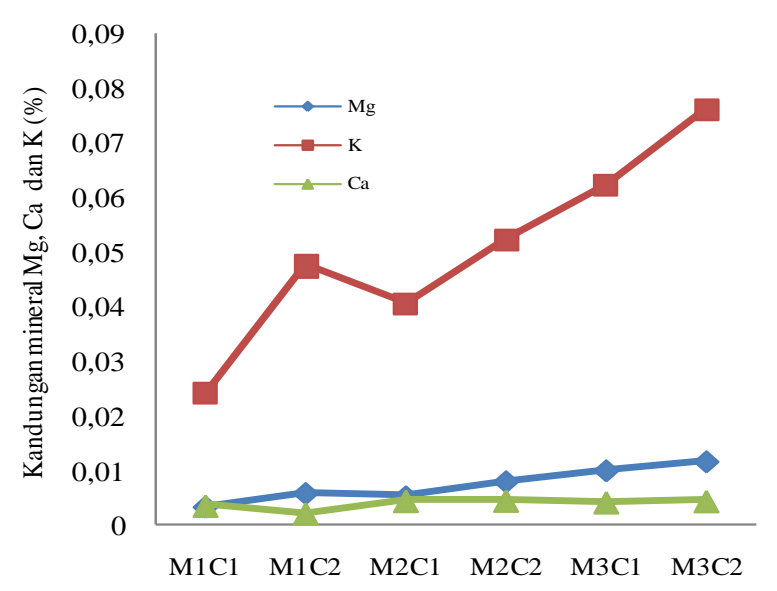

Gambar 1. Grafik kandungan mineral $\mathrm{Mg}, \mathrm{Ca}$ dan $\mathrm{K}$ konsentrat sari buah kundur

Kandungan mineral kalium yang cukup tinggi ini menyebabkan buah kundur ini dipercaya dapat bermanfaat untuk kesehatan dan telah terbukti dari beberapa penelitian sebagai obat hipertensi. Selain kedua mineral di atas, konsentrat buah ini juga mengandung mineral kalsium (Gambar 1), namun tidak sebanyak kandungan magnesium maupun kalium. Buah kundur merupakan buah yang kaya kandungan kaliumnya (Yulia et al., 2020). Studi farmakologis mengungkapkan bahwa tanaman buah kundur bermanfaat untuk kegiatan farmakologis, termasuk efek saraf pusat (anxiolytic, pelemas otot, anti depresan, dalam pengobatan penyakit Alzheimer dan untuk meminimalkan rasa nyeri, antioksidan, antiinflamasi, analgesik, antiastatik, diuretic, nefroprotektif, antidiabetes, hipolipidemik dan efek antimikroba (Al-Snafi, 2013).

Pada konsentrat sari buah kundur juga dilakukan pengamatan terhadap kandungan vitamin C seperti tampak pada Gambar 2. Kandungan vitamin $\mathrm{C}$ konsentrat sari buah kundur berkisar pada nilai 0,00560,0076\%, dengan nilai kandungan vitamin $\mathrm{C}$ tertinggi terdapat pada perlakuan $\mathrm{M} 3 \mathrm{C} 1$ dan terendah pada perlakuan M3C2. Jika di bandingan dengan kadar awal dari sari buah terlihat bahwa terjadi sedikit perbedaan dari nilai vitamin $\mathrm{C}$ yang didapatkan setelah menjadi konsentrat. Naik turunnya kadar vitamin C pada produk konsentrat sangat dipengaruhi oleh proses pengolah konsentrat. Penggunaan suhu yang tidak stabil, atau terlalu tinggi dan waktu pemanasan akan mempengaruhi kandungan vitamin $\mathrm{C}$ yang terdapat pada konsentrat.

Menurut (Farikha et al., 2013), menyatakan bahwa salah satu vitamin yang larut dalam air adalah vitamin $\mathrm{C}$. Vitamin $\mathrm{C}$ bersifat stabil dalam media asam, tetapi pada 
media netral dan basa sangat mudah terdegradasi oleh panas. Laju degradasi asam askorbat sebanding dengan konsentrasi oksigen terlarut dalam bahan pangan, stabilitas asam askorbat akan meningkat dengan menurunnya nilai $\mathrm{pH}$, dan menurut Fatariah et al (2015) menyatakan bahwa buah kundur merupakan salah satu buah/sayuran yang berpotensi sebagai bahan pangan, dikarenakan cukup mengandung asam askorbat yang berguna bagi kesehatan.

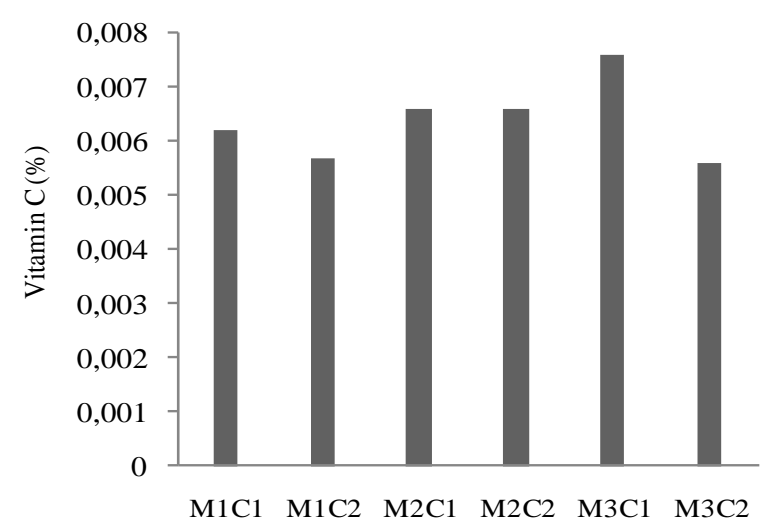

Gambar 2. Grafik kandungan vitamin $\mathrm{C}$ konsentrat sari buah kundur

Nilai aktivitas antioksidan pada konsentrat kundur (Gambar 3), yang didapatkan berkisar pada nilai $38,58 \%-58,65 \%$. Terdapat penurunan nilai aktivitas antioksidan pada perlakuan $\mathrm{M} 3 \mathrm{C} 1$, dan sedikit peningkatan pada perlakuan $\mathrm{M} 3 \mathrm{C} 2$. Terjadinya hal ini kemungkinan karena faktor perlakuan penyaringan dengan ukuran mesh yang berbeda dan proses pengolahan yang dilakukan. Dalam pembuatan konsentrat, penggunaan suhu yang tidak stabil dapat mempengaruhi ativitas antioksidan dan kadar vitamin $\mathrm{C}$ konsentrat yang sangat sensitif dengan perubahan suhu.

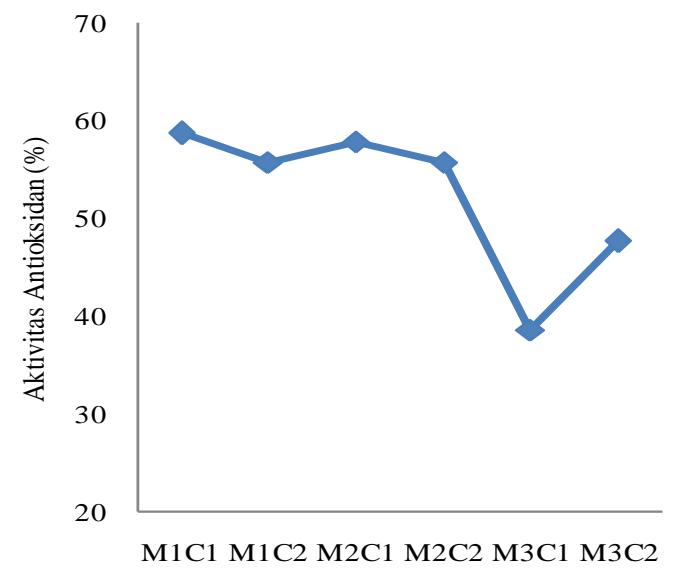

Gambar 3. Aktivitas antioksidan konsentrat sari buah kundur

Antioksidan merupakan suatu senyawa yang dapat menunda atau mencegah oksidasi dengan cara menghambat terjadinya reaksi rantai oksidatif. Fungsi utama antioksidan adalah menetralisasi radikal bebas, sehingga tubuh terlindungi dari berbagai macam penyakit degeneratif. Antioksidan dewasa ini banyak digunakan dalam industri pangan. Antioksidan yang sering digunakan umumnya berupa antioksidan sintetik, antara lain butylated hydroxytoluene (BHT) dan butylated hydroxyanisole (BHA) (Irnawati et al., 2017).

\section{Kesimpulan}

Proses pembuatan konsentrat dengan menggunakan perlakuan variasi ukuran saringan dan perbedaan konsentrasi gula memberikan hasil yang berbeda pada pengamatan kekentalan, kadar gula, kadar serat, kandungan mineral terutama kalsium, kandungan vitamin $\mathrm{C}$ dan aktivitas antioksidan dari konsentrat yang dihasilkan. Perlakukan ukuran saringan 40 mesh dan konsentrasi gula 40\% (M1C2) memberikan hasil yang optimal, dengan $\mathrm{pH} 4,87$, kekentalan 12,09 cP, kadar serat $0,15 \%$, kadar gula $29,91 \%$, kandungan mineral kalsium (Ca) 0,0002\%, magnesium (Mg) 0,0057\%, kalium (K) 0,0474 \% dengan kadar vitamin C 0,0057\% dan aktivitas antioksidan 55,65\%.

\section{Ucapan terima kasih}

Terima kasih disampaikan kepada Bapak Ibu di laboratorium dan Kepala Baristand Industri Padang yang telah banyak memberikan sumbang saran dan membantu kegiatan penelitian ini.

\section{Daftar pustaka}

Adnan, A., Mushtaq, M., Islam, T. ul, 2018. Fruit juice concentrates. fruit juices extr. compos. qual. anal. 217-240. https://doi.org/10.1016/B978-0-12-8022306.00012-6

Al-Snafi, A.E., 2018. Arabian medicinal plants with analgesic and antipyretic effects- plant based review (Part 1). Iosr J. Pharm. 8, 77-95.

Al-Snafi, A.E., 2013. The pharmacological importance of Benincasa hispida. A review. Int. J. Pharma Sci. Res. 4, 165-170.

Asmawati, A., Sunardi, H., Ihromi, S., 2018. Kajian persentase penambahan gula terhadap komponen mutu sirup buah Naga Merah. J. Agrotek Ummat 5, 97. https://doi.org/10.31764/agrotek.v5i2.700

Bastanta, D., Karo-Karo, T., Rusmarilin, H., 2017. Pengaruh perbandingan sari sirsak dangan sari Bit Dan. J. Rekayasa Pangan dan Pertan. 5, 102-108.

Bhattacharjee, C., Saxena, V.K., Dutta, S., 2017. Fruit juice processing using membrane technology: A review. Innov. Food Sci. Emerg. Technol. 43, 136153. Https://doi.org/10.1016/j.ifset. 2017.08 .002

Chen, L., Huang, G., 2019. Antioxidant activities of sulfated pumpkin polysaccharides. Int. J. Biol. Macromol. 126, 743-746. https://doi.org/10.1016/ j.ijbiomac.2018.12.261

Das, J.K., Hazarika, M., Das, A., Gogoi, P., Hussain, P., Kalita, D.J., Nahardeka, N., 2019. Effect of Kumura (Benincasa hispida) on the physico-chemical and storage quality characteristics of Duck meat loaves. Int. J. Curr. Microbiol. Appl. Sci. 8, 2772-2783. https://doi.org/10.20546/ijcmas. 2019.802.325

Ekeke, C., Ogazie, C.A., Agbagwa, I.O., 2019. Anatomical and phytochemical studies on Benincasa 
hispida (Thunb.) Cogn. (Cucurbitaceae). Not. Sci. Biol. 11, 102-111. https://doi.org/10.15835/ nsb11110394

Farikha, I.N., Anam, C., Widoeati, E., 2013. Pengaruh jenis dan konsentrasi bahan penstabil alami terhadap karakteristik fisikokimia sari buah Naga Merah (Hylocereus polyrhizus) selama penyimpanan. J. Teknosains Pangan 2, 30-38.

Fatariah, Z., Tengku Zulkhairuazha, T.Y., Wan Rosli, W.I., 2015. Ascorbic acid quantification in Benincasa hispida fruit extracted using different solvents. Int. Food Res. J. 22, 208-212.

Fitri, E., Harun, N., Johan, V.S., 2017. Konsentrasi gula dan sari buah terhadap kualitas sirup belimbing wuluh (Averrhoa bilimbi L.). JOM Faperta UR 4, 113.

Hamidi, F., Efendi, R., Hamzah, F., 2016. Penambahan sari jeruk nipis (Citrus aurantifolia) terhadap mutu sirup buah kundur (Benincasa hispida). Jom Faperta UR 3, 1-15.

Irnawati, Purba, M., Mujadilah, R., Sarmayani, 2017. Penetapan kadar vitamin $\mathrm{C}$ dan uji aktifitas antioksidan sari buah Songi (Dillenia serrata Thunb.) terhadap radikal DPPH (diphenylpicrylhidrazyl). Pharmacon 6, 40-44. https://doi.org/10.35799/pha. 6.2017.16419

Kumar, K., Srivastav, S., Sharanagat, V.S., 2020. Ultrasound assisted extraction (UAE) of bioactive compounds from fruit and vegetable processing bypriducts : A review. Ultrason. - Sonochemistry 70, 111. https://doi.org/10.1201/9781420000955-29

Luhurnintyas, F.P., Vifta, R.L., Khitimah, S.K., 2018. Uji aktivitas anti jamur ekstrak biji Bligo (Benincasa hispida (Thunb.) Cogn.) terhadap pertumbuhan jamur
(Candida albicans). Indones. J. Pharm. Nat. Prod. 1, 30-35.

Mubarak, F., Sartini, S., Purnawanti, D., 2018. Effect of ethanol concentration on antibacterial activity of Bligo fruit extract (Benincasa hispida Thunb) to Salmonella typhi. Indones. J. Pharm. Sci. Technol. 5, 76. https://doi.org/10.24198/ijpst.v5i3. 16444

Pan, X., Zhang, W., Lao, F., Mi, R., Liao, X., Luo, D., $\mathrm{Wu}, \mathrm{J} ., 2020$. Isolation and identification of putative precursors of the volatile sulfur compounds and their inhibition methodes in heat-sterilized melon juices. Food Chem.

Sun, X., Baldwin, E., Plotto, A., Cameron, R., Manthey, J., Dorado, C., Bai, J., 2018. The effect of cultivar and processing methode on the stability, flavor, and nutritional properties of winter melon juice. LWTFood Sci. Technol. https://doi.org/10.1016/j.lwt. 2018.06.059.This

Suryanti, V., Marliyana, S.D., Musmualim, M., 2018. Identifikasi senyawa kimia dalam Buah Kundur (Benincasa hispida (Thunb) Cogn.) dengan Kromatografi Gas-Spektrometer Massa (KG-SM). ALCHEMY J. Penelit. Kim. 14, 84-94. https://doi.org/10.20961/alchemy.14.1.13496.100110

Yulia, R., Handayani, N., Juliani, 2020. Pengaruh buah Kundur (Benincasa hispida) dan Buah Nanas (Ananas comosus L . Merr) rasio serta konsentrasi gula terhadap mutu fruit leather V, 995-1002.

Zaini, N.A.M., Anwar, F., Hamid, A.A., Saari, N., 2011. Kundur [Benincasa hispida (Thunb.) Cogn]: A potential source for valuable nutrients and functional foods. Food Res. Int. 44, 2368-2376. https://doi.org/10.1016/j.foodres.2010.10.024 